\title{
The Carolingian Past in Post-Carolingian Europe
}

Simon MacLean

On 28 January 893, a 13-year-old known to posterity as Charles III "the Simple" (or "Straightforward") was crowned king of West Francia at the great cathedral of Rheims. Charles was a great-great-grandson in the direct male line of the emperor Charlemagne andclung tightly to his Carolingian heritage throughout his life. ${ }^{1}$ Indeed, 28 January was chosen for the coronation precisely because it was the anniversary of his great ancestor's death in 814 . However, the coronation, for all its pointed symbolism, was not a simple continuation of his family's long-standing hegemony - it was an act of rebellion. Five years earlier, in 888, a dearth of viable successors to the emperor Charles the Fat had shattered the monopoly on royal authority which the Carolingian dynasty had claimed since 751 . The succession crisis resolved itself via the appearance in all of the Frankish kingdoms of kings from outside the family's male line (and in some cases from outside the family altogether) including, in West Francia, the erstwhile count of Paris Odo - and while Charles's family would again hold royal status for a substantial part of the tenth century, in the long run it was Odo's, the Capetians, which prevailed. Charles the Simple, then, was a man displaced in time: a Carolingian marooned in a post-Carolingian political world where belonging to the dynasty of Charlemagne had lost its hegemonic significance, however loudly it was proclaimed. ${ }^{2}$ His dilemma represents a peculiar syndrome of the tenth century and stands as a symbol for the theme of this article, which asks how members of the tenth-century ruling class perceived their relationship to the Carolingian past.

The relationship between the high Carolingian age of Charlemagne and the post- 888 era of Charles the Simple has, in one form or another, long played a part in debates about the shift from the early to the central Middle Ages. At least since the formidable work of Georges Duby in the early 1950s, discussion of the tenth century in the Frankish world has been wrapped up in debates about periodization that revolve around two paradigms: the existence or otherwise of the so-called "Feudal Revolution" (or "Mutation") of the year 1000; and the pre-history of the papal reforms of the eleventh century. ${ }^{3}$ Depending on where one stands in these debates, the tenth century is variously characterised as a relatively serene continuation of the Carolingian "project", as the last gasp of Late Antiquity, or as a Dark Age of collapse from whose rubble the kingdoms and institutions of medieval Europe would begin to emerge only in the mid-eleventh. ${ }^{4}$ Viewed in such terms, the tenth century is either a beginning or an

\footnotetext{
${ }^{1}$ Bernd Schneidmüller, Karolingische Tradition und frühes französisches Königtum: Untersuchungen zur Herrschaftslegitimation der westfränkisch-französischen Monarchie im 10. Jahrhundert (Wiesbaden, 1979); Geoffrey Koziol, The Politics of Memory and Identity in Carolingian Royal Diplomas: the West Frankish Kingdom (840-987) (Turnhout, 2012).

${ }^{2}$ On the significance of the Carolingian royal monopoly and its disappearance in 888 see Stuart Airlie, Power and its Problems in Carolingian Europe (Farnham, 2012).

${ }^{3}$ Georges Duby, La Société aux XIe et XIIe siècles dans la région mâconnaise (Paris, 1953); Stephen D. White, "Tenth-Century Courts at Mâcon and the Perils of Structuralist History: Re-Reading Burgundian Judicial Institutions," in Warren C. Brown and Piotr Górecki (eds.), Conflict in Medieval Europe: Changing Perspectives on Society and Culture (Aldershot, 2003), pp. 37-68.
}

${ }^{4}$ See for example the various articles debating the Feudal Revolution in Past and Present between 1994 and 1997 prompted by Thomas Bisson, "The Feudal Revolution," Past and Present 142 (1994), 6-42; Richard Sullivan, "The Carolingian Age: Reflections on its Place in the History of the Middle Ages," Speculum 64 (1989), pp. 267-306. A clear discussion of 
end, lacking definition of its own - a shadowy valley separating the towering peaks of Charlemagne and Gregory VII.

Historical periodization is a problematic business, and despite the dates in its subtitle it is one of the virtues of Robert Bartlett's Making of Europe that it provides a panoramic perspective on these debates without becoming embroiled in their minutiae. Arguing that Europe was a product of the "fertile confusion" of the post-Carolingian period, Bartlett sees the tenth century neither as an end nor a beginning, but as part of a longer period with its own cultural traits dispersed by military-colonial expansion from the Frankish heartlands to the European peripheries. ${ }^{5}$ This "soft" periodization avoids the methodological traps of strict debates about continuity vs change and recognises that all apparently stable systems contain the roots of their own change. ${ }^{6}$ The Making of Europe does emphasise some distinctions between the social and political characteristics of the early and central Middle Ages, but its panoramic and undogmatic description of the post-Carolingian period also anticipates more recent views of the era's religious and social changes as emergent consequences of, rather than radical breaks with, the structures and expansionary impulses of the Carolingian Empire. $^{7}$

Whereas the debates about the emergence of Europe from the wreckage of the empire deal mainly with the chronologies of social and economic history, what follows turns instead to the complementary matter of perception. In what ways did members of the ruling class north of the Alps in the tenth and early eleventh centuries feel themselves connected to the ninth century past? To what extent was the post-Carolingian period from which Bartlett's Europe evolved perceived as such by those who lived in it? It would be easy to assume that Carolingian narratives about the past colonised and helped create the European imagination as part of the process by which Frankish cultural models were exported and imposed. After all, Europe is not just a region but also an idea, and the Frankish imperial past was an obvious touchstone for that idea. ${ }^{8}$ It was not by accident that the colonial aristocracies which created high medieval Europe described themselves as "Franks", a hegemonic identification whose roots lay in the triumphal narratives generated by an earlier phase of European expansion under Charlemagne. ${ }^{9}$ Charlemagne's imperialist achievements were euphemised by his apologists into his benevolent status as "Father of Europe" (pater Europae), and there is little

the debate is provided by Charles West, Reframing the Feudal Revolution: Political and Social Transformation Between Marne and Moselle, c.800-c.1100 (Cambridge, 2013). ${ }^{5}$ Robert Bartlett, The Making of Europe: Conquest, Colonization and Cultural Change, 9501350 (London, 1993), pp. 2 (rejection of 1000 as a sharp turning point), 311 (quotation).

${ }^{6}$ Chris Wickham, "Historical Transitions: A Comparative Approach," The Medieval History Journal 13 (2010), 1-21. For an even broader perspective see Paul Fouracre, "Francia and the History of Medieval Europe," Haskins Society Journal 23 (2011), 1-21.

${ }^{7}$ West, Reframing the Feudal Revolution; Sarah Hamilton, Church and People in the Medieval West, 900-1200 (London, 2013); Wickham, "Historical Transitions," 14-17. See also Timothy Reuter, "Modern Mentalities and Medieval Polities," in Timothy Reuter, Medieval Polities and Modern Mentalities, ed. Janet L. Nelson (Cambridge, 2006), pp. 3-18, at pp. 5-6, for comments on the tendency of English-language scholarship to neglect a truly European perspective (with Making of Europe an exception, alongside the work of Richard Southern and Susan Reynolds).

${ }^{8}$ Bartlett, Making of Europe, p. 1.

${ }^{9}$ Bartlett, Making of Europe, pp. 85-105. For the earlier development of Frankishness see Rosamond McKitterick, History and Memory in the Carolingian World (Cambridge, 2004). 
doubt that he was remembered in something like that capacity by posterity, from the opening of his grave by Otto III in 1000 via his canonisation by Frederick I Barbarossa in 1165 to his modern reinventions in the ideologies of the Nazis and the founders of the European Union. ${ }^{10}$ Modern accounts of this posthumous career tend to see it as more or less continuous, with his reign rapidly becoming a golden age from the moment of his death in $814 .{ }^{11}$ It would therefore be easy to presume that Carolingian glamour hung heavy in the air of tenth-century Europe, ready for use by rulers and intellectuals seeking to legitimise contemporary actions with reference to precedent. In this view, Charles the Simple's celebration of his ancestors was merely a particularly clear example of a perennial political desire to appropriate the Carolingian past in the service of the present. ${ }^{12}$ On one level this is obviously true: the Carolingians were hardly forgotten. But in what follows I will argue (following Tim Reuter) that the evidence for the instrumentalisation of Carolingian history in the successor kingdoms of the tenth century can also be viewed as a glass half empty - and that, therefore, a sense of distance from the past was another of the things that defined the period as post-Carolingian. ${ }^{13}$ A short article can hardly do full justice to the topic, so will be restricted to brief discussion of three samples of evidence.

The first is the body of references to the Carolingian past in post-Carolingian narratives. Fabulously detailed studies of manuscript transmission have demonstrated the extent to which biographies of Carolingian rulers and histories celebrating their deeds were disseminated, read and copied across Europe between the tenth and twelfth centuries. ${ }^{14}$ That contemporaries realised the potential of this material for framing narratives of the postCarolingian world is clear from the example of Adalbert of Magdeburg, whose triumphal account of the Ottonian dynasty down to 967 was written as a continuation of Regino of Prüm's history of the rise and fall of the Carolingians, and thus presented his patrons Otto I and Otto II as inheritors and renewers of the Frankish empire in the West. ${ }^{15}$ Charlemagne in

${ }^{10}$ Max Kerner, Karl der Grosse. Entschleierung eines Mythos (Cologne, Weimar and Vienna, 2000); Robert Morrissey, Charlemagne and France: A Thousand Years of Mythology (Notre Dame, 2003); Janet Nelson, "Charlemagne - Father of Europe?" in Janet Nelson, Courts, Elites and Gendered Power in the Early Middle Ages: Charlemagne and Others (Aldershot, 2007); Anne Latowsky, Emperor of the World: Charlemagne and the Construction of Imperial Authority, 800-1229 (Ithaca, 2013).

${ }^{11}$ Bernd Schütte, "Karl der Große in der Geschichtsschreibung des hohen Mittelalters," in Bernd Bastert (ed.), Karl der Grosse in der europäischen Literaturen des Mittelalters (Tübingen, 2004), pp. 223-245.

12 Matthew Gabriele, An Empire of Memory: the Legend of Charlemagne, the Franks and Jerusalem Before the First Crusade (Oxford, 2011), p. 20; Latowsky, Emperor of the World, pp. 15-16. For various reflections on matters of continuity and change see Bernd Schneidmüller and Stefan Weinfurter (eds.), Ottonische Neuanfänge: Symposion zur Ausstellung "Otto der Grosse, Magdeburg und Europa" (Munich, 2001).

${ }^{13}$ Timothy Reuter, "Regemque, quem in Francia pene perdidit, in patria magnifice recepit: Ottonian Ruler Representation in Synchronic and Diachronic Comparison," in Reuter, Medieval Polities, pp. 127-146, at pp. 135-7; Timothy Reuter, "The Ottonians and Carolingian Tradition," in Reuter, Medieval Polities, pp. 268-283.

${ }^{14}$ E.g. Matthias Tischler, Einharts Vita Karoli: Studien zur Entstehung, Überlieferung und Rezeption (Hanover, 2001).

${ }^{15}$ Adalbert, Continuatio, ed. Friedrich Kurze, Reginonis abbatis prumiensis Chronicon, cum continuatione treverensi, MGH SRG (Hanover, 1890), pp. 154-179; Bernhard Zeller, "Die Liudolfinger als fränkische Könige? Beobachtungen zur sogenannten Continuatio 
particular was clearly a figure of considerable stature in the political discourse of the Ottonian ruling class - the "great Charles" was, for example, referred to as a yardstick for the reputation of Otto I in the early-eleventh century chronicle of Thietmar of Merseburg. ${ }^{16}$ However, there is a lot less of this kind of thing than one might expect. It is quite surprising how infrequently the Carolingians appear in tenth-century sources, and with only a handful of exceptions (like the passage from Thietmar) even Charlemagne is not held up as an explicit model for Ottonian rulers. One reason for this is that the Ottonians came from Saxony, a region which was conquered and Christianized by Charlemagne but remained peripheral to the itineraries of Carolingian kings. The Ottonian version of Charlemagne was lifted from the pages of Saxon hagiography rather than the triumphalist political narratives of Einhard and the Royal Frankish Annals. He was depicted less as a great ruler than as a founder of churches and converter of pagans, and his memory was much more likely to be invoked in disputes over ecclesiastical organisation and the eastwards expansion of Christendom than in discussions about kingship per se. ${ }^{17}$ That it could easily have been otherwise is made clear from the Deeds of the Saxons written in the 960s by Widukind of Corvey, who clearly knew about Charlemagne via Einhard's biography and the Royal Frankish Annals but only used them in passing (most notably in a parenthetical passage on Otto I's physical appearance). ${ }^{18}$ Unlike the Carolingian historians of the later ninth century, or the world chroniclers of the twelfth, both of which groups habitually invoked Charlemagne's reign as a golden age against which to measure his descendants, Widukind was a dog who didn't bark - a writer who was well aware of the rich historiographical resources left by his predecessors, but nonetheless chose not to make much use of them.

The starting points of histories are important indicators as to the stories that their authors wish to tell. ${ }^{19}$ One striking thing about the long-form histories of the tenth century is that most of them begin either at the very end of the Carolingian empire in the 880s or at the beginning of the reign of the first Ottonian ruler Henry I in 919 and made no real attempt to link the end of the old empire to the beginnings of its successor kingdoms: this is the case for Richer of Rheims, Liudprand of Cremona, Hrotsvitha of Gandersheim and Flodoard of Rheims (even though his knowledge of the ninth century is clear from his other works). ${ }^{20}$ Even those texts that do delve into a deeper past do not really make a case for continuity. Widukind roots his story in legendary post-Roman encounters between Franks and Saxons and makes a point of stressing that Henry I won his empire rather than inheriting it - despite the fact that inheritance/continuity was a story that could have been spun via the well-known

Reginonis," in Richard Corradini et al (eds.), Texts and Identities in the Early Middle Ages (Vienna, 2006), pp. 137-152.

16 Thietmar, Chronicon, ed. Robert Holtzmann, Die Chronik des Bischofs Thietmar von Merseburg und ihre Korveier Überarbeitung, MGH SRG NS 9 (Berlin, 1935), 2.45, pp. 9293.

${ }^{17}$ Hagen Keller, "Die Ottonen und Karl der Große," Frühmittelalterliche Studien 34 (2000), pp. 112-131.

${ }^{18}$ Widukind of Corvey, Rerum Gestarum Saxonicarum Libri Tres, ed. Paul Hirsch, MGH SRG (Hanover, 1935), 2.36, pp. 95-97; Sverre Bagge, Kings, Politics and the Right Order of the World in German Historiography, c. 950-1150 (Leiden, Boston and Cologne, 2002), pp. 58-59.

${ }^{19}$ Robert Bartlett, England under the Norman and Angevin Kings, 1075-1225 (Oxford and New York, 2000), pp. 619-620.

${ }^{20}$ Reuter, "Ottonians and Carolingian Tradition". 
marriage of Henry's grandfather to a Carolingian princess. ${ }^{21}$ Even Adalbert qualified his implicit point about continuity with his declaration that with the death of Louis the Child in 911, "the royal line had now failed." 22 In fact, the first time that Carolingian descent was claimed for an Ottonian king seems to have been in Adalbold of Utrecht's biography of Henry II, written $c$. 1012. A manifestly fanciful genealogy from the same period makes a similar claim about his wife Cunigunde. ${ }^{23}$ But these attempts to appropriate Carolingian heritage were made as only one strand of argument among many during a complicated succession dispute in which all the competitors enjoyed very similar claims to legitimacy. Only in this extremely unusual situation was Carolingian continuity of this kind seen as a card worth playing. ${ }^{24}$

This apparent lack of interest at the political centre in asserting the continuity of the present from the past, even when such claims were available, or could be confected, is compounded by indications that historians of the tenth century frequently made mistakes when referring to Carolingian history. ${ }^{25}$ With this in mind, it is also noticeable that several important authors of this period had a particular blind spot in the decades around 900. The Quedlinburg Annals, begun at the end of the tenth century, provide a history of the world going back to the creation which, although scrupulously constructed from a wide variety of sources, leaves the years 874-909 almost completely blank. This ignorance is particularly striking in that Quedlinburg was one of the institutions where the liturgical commemoration of the Ottonian dynasty was cultivated, and the annals both drew on and inspired several other important histories which shared the same gap. ${ }^{26}$ A similar caesura (between 887 and 925) can be found in the Deeds of the Bishops of Verdun, begun in the first half of the tenth century and continued in the eleventh. ${ }^{27}$ Folcuin of Lobbes (near Liège), writing a history of his abbey

${ }^{21}$ Widukind, Rerum Gestarum Saxonicarum Libri Tres, 1.41, pp. 60-61.

${ }^{22}$ Adalbert, Continuatio, s.a. 911, p. 155.

${ }^{23}$ Karl Schmid, "Ein verlorenes Stemma Regum Franciae: Zugleich ein Beitrag zur Entstehung und Funktion karolingischer (Bild-)Genealogien in salisch-staufischer Zeit," Frühmittelalterliche Studien 28 (1994), 196-225; Karl Schmid, "Geschlechterbewußtsein am Beispiel ausgewählter karolingischer (Bild-)Stemmata aus dem hohen Mittelalter," in Claudie Duhamel-Amado and Guy Lobrichon (eds.), Georges Duby. L'écriture de l'histoire (Brussels, 1996), pp. 141-59.

${ }^{24}$ Adalbold of Utrecht, Vita Heinrici II imperatoris, cc. 1-2, ed. Markus Schütz, "Adalbold von Utrecht, Vita Heinrici II imperatoris: Übersetzung und Einleitung," Bericht des Historischen Vereins für die Pflege der Geschichte des ehemaligen Fürstbistums Bamberg 135 (1999), 148-195, at 150-154. On this and the other claims made in the dispute see Steffen Patzold, "Königserhebungen zwischen Erbrecht und Wahlrecht? Thronfolge und Rechtsmentalität um das Jahr 1000," Deutsches Archiv für Erforschung des Mittelalters 58 (2002), 467-507; Stefan Weinfurter, "Authority and Legitimation of Royal Policy and Action. The Case of Henry II," in Gerd Althoff et al (eds.), Medieval Concepts of the Past. Ritual, Memory, Historiography (Cambridge, 2002), pp. 19-37.

${ }^{25}$ Reuter, "Ottonians and Carolingian Tradition."

${ }^{26}$ Annales Quedlinburgenses, ed. Martina Giese, MGH SRG 72 (Hanover, 2004), pp. 306310,452 . Giese's discussion demonstrates that is not likely to be an effect of defects in the manuscript transmission. The story picks up again (s.a. 913, pp. 453-454) with the birth of Otto I and the Ottonianisation of the future: "[Otto the Illustrious] dux praecipuus, de quo velut fertilissimo quodam stemmate imperatoria illa Otthonum propago totius Europae terminis non modicum profutura processit."

${ }^{27}$ Gesta episcoporum Virdunensium, ed. Georg Waitz, MGH SS 4 (Hanover, 1841), p. 45. 
around 980, describes the decades after the death of Charles the Bald (d. 877) not only as a period marked by the end of hereditary kingship and confusion in the royal sphere, but even as an "interregnum". ${ }^{28}$ This is not a common word in early medieval sources but could be highly ideological - it appears, for example, in some early Carolingian condemnations of the weakness and discontinuity of Merovingian kingship. ${ }^{29}$ Folcuin is overtly unsure about the sequence of kings in this section of his otherwise meticulously-researched narrative. Even Adalbert, an author who was interested in emphasising continuity, is very unclear about events before the end of the 930s, to which point many of his entries are single sentences lifted from the equally sketchy monastic annals he had to rely on for sources.

And given that Adalbert had learned his Carolingian history from Regino of Prüm, what's perhaps more surprising still is that Regino himself, though he was finished writing as early as 908 and lived in the kingdom of the Carolingian ruler Louis the Child, appears to have had only the slenderest grasp of ninth-century chronology. Although he was able to tell the story of Charlemagne's reign word-for-word as he discovered it in the Royal Frankish Annals, he seems not to have been especially familiar with, or impressed by, that source: "I discovered the things which have been laid out above in a certain booklet composed in the language of plebeians and rustics." Of Charlemagne's son and successor Louis Pious he knew even less, "because I have not found written texts, nor heard from the seniores anything that was worth committing to memory." 30 Moreover, what he knew about Lothar II, one of the key figures in his narrative, appears to have derived from a collection of letters surviving in a single manuscript which he had been fortunate to stumble upon. ${ }^{31}$ When reading Regino's protestations about the limitations of his knowledge and the difficulty of finding sources, we should remember that he was no provincial rustic himself - Prüm, where he had been abbot, was a large monastery with impeccable Carolingian connections, and a major culturalpolitical centre. The archiepiscopal seat of Trier, where he wrote his history, was anotherand also where a much-copied biography of Louis the Pious had been written a few decades earlier. Regino's blind-spots are therefore surprising, and worthy of note.

How might we understand these silences separating narratives of the Carolingian era from those of the Ottonians? Part of the answer might be that the Ottonians and their apologists did not want to compete for a Carolingian identity when the descendants of Charles the Simple, who ruled west Francia between 936 and 987, were in a position to outbid them in that game. ${ }^{32}$ However, it was not an easy matter for new political regimes to simply cast off the symbols of their predecessors if those symbols still carried cultural weight. ${ }^{33}$ Nor is it at all clear that any of the Ottos, whose political and expansionary energies were mainly directed to the east and south, cared much about the sensitivities of their weaker neighbours in the west (at least after about 950). When they did clash, as when King Lothar occupied the iconic

\footnotetext{
${ }^{28}$ Folcuin, Gesta Abbatum Lobbiensium, ed. Waitz, MGH SS 4, cc. 15, 16, 19, pp. 61-63.

${ }^{29}$ Rosamond McKitterick, Charlemagne: the Formation of a European Identity (Cambridge, 2008), pp. 70-71.

${ }^{30}$ Regino, Chronicon, s.a. 813, p. 73. For discussion see Stuart Airlie, “Sad stories of the deaths of kings': Narrative Patterns and Structures of Authority in Regino of Prüm's Chronicon," in Airlie, Power and its Problems.

${ }^{31}$ Charles West, "Regino of Prüm and the Lost Manuscript: Knowledge of the Past and the Judgement of History in Tenth-Century Trier," Early Medieval Europe (forthcoming).

${ }^{32}$ Reuter, "Ottonians and Carolingian Tradition," p. 278.

33 Thomas Sizgorich, "Narrative and Community in Islamic Late Antiquity," Past and Present 185 (2004), 9-42.
} 
Carolingian palace of Aachen in 978 and then suffered a retaliatory invasion by Otto II, the indications are that they saw each other as simple antagonists with anxieties about their shared frontier rather than as competitors for the potent symbols of a shared history. Tenthand eleventh-century descriptions of these events elaborate little on the palace's association with its founder Charlemagne, and sources written in the empire even use 'Carolingian' as a derogatory term for the West Frankish rulers and their people. ${ }^{34}$

Perhaps, then, we should think in terms of a more profound type of cultural "forgetting" such as that argued by Patrick Geary to have characterised the eleventh century. ${ }^{35}$ This need not reflect ignorance of the past per se, as opposed to a shift of categories - perhaps postCarolingian writers did not "know" about the Carolingian past precisely because it did not matter to them as much as we might think. We should remember here that the tight-knit ninth-century world of historical writing, in which different authors responded to, critiqued and continued each other's work, fizzled out completely in the first decade of the tenth, with no long-form histories written in the East Frankish kingdom between those of Regino in 908 and Liudprand of Cremona half a century later (and a similar silence in West Francia broken only by the regional histories of Flodoard of Rheims). This silence coincides with a wider political uncertainty occasioned by the end of the Carolingian monopoly on royal power in 888 , after which dynastic politics became markedly unpredictable, with different families competing for thrones and sons rarely succeeding their fathers. Given that the ninth-century boom in the writing of annals patterned around the movements of kings was underpinned by the relative stability of Carolingian hegemony, then the end of those narratives can be seen as a symptom of the dynastic instability that characterised the decades either side of 900 - how could histories be written towards and about the political centre now that it had become a site of constant competition between rival families? To borrow a term coined by historians of the late Roman period, it might be useful to think of a post-Carolingian "crisis of representation" in which it became difficult to purposefully rewrite the past because of the uncertainty of the present. ${ }^{36}$ And when narrative histories reappeared after this period of "crisis", they were mainly written in and focused on alternative centres of power - churches, especially bishoprics - than on royal courts. ${ }^{37}$ This period of historiographical silence caused by political rupture has a parallel in post-Conquest England. In each case, when history writing re-emerged after a couple of generations, authors accommodated the past to the present in

${ }^{34}$ Theo Riches, "The Carolingian Capture of Aachen in 978 and its Historiographical Footprint," in Paul Fouracre and David Ganz (eds.), Frankland: the Franks and the World of the Early Middle Ages. Essays in Honour of Dame Jinty Nelson (Manchester, 2008), pp. 191208, esp. pp. 203-5 and 207-8.

${ }^{35}$ Patrick Geary, Phantoms of Remembrance: Memory and Oblivion at the End of the First Millennium (Princeton, 1994).

${ }^{36}$ Gerda Heydemann, "Biblical Israel and the Christian gentes: Social Metaphors and the Language of Identity in Cassiodorus's Expositio Palmarum," in Walter Pohl and Gerda Heydemann (eds.), Strategies of Identification: Ethnicity and Religion in Early Medieval Europe (Turnhout, 2013), pp. 143-208, at pp. 145-146. For another parallel see Chris Wickham, "Lawyer's Time: History and Memory in Tenth- and Eleventh-Century Italy," in Henry Mayr-Harting and Robert I. Moore (eds.), Studies in Medieval History Presented to R.H.C. Davis (London, 1985), pp. 53-71.

${ }^{37}$ Theo Riches, "The Changing Political Horizons of gesta episcoporum from the Ninth to the Eleventh Centuries," in Ludger Körntgen and Dominik Waßenhoven (eds.), Patterns of Episcopal Power: Bishops in Tenth and Eleventh Century Western Europe (Berlin, 2011), pp. 51-62. 
various ways that do not necessarily map onto our own debates about continuity vs change. ${ }^{38}$ If the Anglo-Saxon past formed an important part of new post-Conquest political discourses, the Ottonians' relatively weak interest in the Carolingian past might be said to have helped construct a specifically post-Carolingian consciousness.

A second sample of evidence concerns the residual tenth-century importance of Aachen, the Carolingian palace founded by Charlemagne towards the end of his reign and associated also with his son Louis the Pious. Four of the five Ottonian kings were crowned there (Ottos I, II and III in 936, 961 and 983 respectively, and Henry II in 1002), as were most members of the German dynasties who succeeded them. In retrospect, this clearly became a regnal tradition, with Aachen elevated to the status of "sacra sedes" by the time of Frederick Barbarossa in the twelfth century and formally designated as the realm's coronation site by Charles IV in the fourteenth. ${ }^{39}$ Without doubt, this was a place with strong Carolingian associations in the postCarolingian age - in 1000, Otto III even exhumed the body of Charlemagne from its grave in the palace chapel, certainly as a way of advertising his admiration, and perhaps as a prelude to proclaiming him a saint. ${ }^{40}$ It has therefore been taken for granted that these dynastic associations were what mattered to the Ottonians above all, and from the beginning. ${ }^{41}$ But we also need to take into account the fact that Aachen's symbolism was anchored in a region, northern Lotharingia, far from the Saxon heartlands of Ottonian power. How might the changed political geography of the post-Carolingian world have influenced the meaning of Ottonian attempts to appropriate the palace?

Here we need to bear in mind that even though Lotharingia had become (with hindsight) a permanent part of the east Frankish kingdom in 925, the north in particular remained contested territory. Otto I visited often enough for Eckhard Müller-Mertens to classify it as a royal heartland in his pioneering study of that ruler's itinerary, but in truth those visits were irregular and concentrated into periods when the western Franks were unable to press their claims. ${ }^{42}$ West Frankish rulers invaded in 939-40, 978 and 985, and at other times took opportunities to advertise their claims rhetorically - the naming of young Lothar in 941 was surely intended to proclaim West Frankish ambitions in "Lothar's realm"; and in 959 those

${ }^{38}$ Bartlett, England Under the Norman and Angevin Kings, pp. 616-633, esp. pp. 618-19.

${ }^{39}$ Heinz Krieg, Herrscherdarstellung in der Stauferzeit: Friedrich Barbarossa im Spiegel seiner Urkunden und der staufischen Geschichtsschreibung (Ostfildern, 2003), pp. 341-342; F.R. Erkens, "Ex iure regni debitus coronatur: zum Krönungsrecht des Kölner Erzbischofs," Zeitschrift des Aachener Geschichtsvereins 104/5 (2002/3), 25-49

${ }^{40}$ Knut Görich, "Otto III. öffnet das Karlsgrab in Aachen. Überlegungen zu

Heiligenverehrung, Heiligsprechung und Traditionsbildung," in Gerd Althoff and Ernst Schubert (eds.), Herrschaftsrepräsentation im ottonischen Sachsen (Sigmaringen, 1998), pp. 381-430.

${ }^{41}$ E.g. Eckhard Müller-Mertens, "The Ottonians as Kings and Emperors," in Timothy Reuter (ed.), The New Cambridge Medieval History vol. 3, c.900-1024 (Cambridge, 1999), pp. 233266, at p. 244.

${ }^{42}$ Eckhard Müller-Mertens, Die Reichsstruktur im Spiegel der Herrschaftspraxis Ottos des Großen (Berlin, 1980). Further discussion in Simon MacLean, "Palaces, Itineraries and Political Order in the Post-Carolingian Kingdoms," in John Hudson and Ana Rodriguez (eds.), Diverging Paths? The Shapes of Power and Institutions in Medieval Christendom and Islam (Leiden, 2014), pp. 291-320. 
ambitions were still thought sufficiently current to warrant a public renunciation. ${ }^{43}$ But Lotharingia's in-betweenness meant that it was tricky for kings on either flank to establish a consistent presence there. ${ }^{44}$ For local observers like Folcuin of Lobbes, the dominant figures were powerful regional aristocrats such as Reginar III of Hainaut, whom he describes as harassing his monastery with impunity during the $950 \mathrm{~s} .{ }^{45}$ Folcuin was sympathetic to Ottonian rule but saw it as distant and mostly absent - at one point he refers to Otto I as "king in the south". ${ }^{46}$ This sense of distance can also be detected in texts written from the perspective of the political centre: a charter of the 960s laments Otto's lack of resources in the region; and when Otto II stayed at Aachen in 973, a contemporary author from Alemannia described him as being "in the remotest corner of his kingdom". 47

A sense of the "middle kingdom" as a kind of in-between zone can also be detected in the ways the Lotharingians were characterised as a gens. According to Ruotger of Cologne, they were a "savage" people until they were tamed by his hero Archbishop Bruno. ${ }^{48}$ For Thietmar of Merseburg, writing nearly half a century later, the Lotharingians (here denied a group label and generically described as "the people of the West") were "always fickle" and displayed a "tendency towards arousal" - they were cowards who resisted the rule of God and king and "serve[d] only their bodily desires." withering ethnographic gaze that the political centre turned towards the "uncivilized" frontier in the age of medieval European expansion. ${ }^{50}$ But here the polarity is reversed as authors in what had hitherto been a border region, itself subject to conquest and Christianization, projected the "image of the barbarian" onto the inhabitants of one of Europe's cultural and economic heartlands. ${ }^{51}$ This geographical shift may be linked to the changes in historical consciousness discussed earlier. Some scholars argue that the persistence of social memory is underpinned by the maintenance of "a stable system of places", and this might be particularly relevant to a society whose characteristic historical genre - annals structured by the progress of the king around the nodal points of his realm - was closely linked to contemporary understandings of space and place. ${ }^{52}$ The inversion of Carolingian political geography

\footnotetext{
${ }^{43}$ Flodoard, Annales, ed. Philippe Lauer, Les Annales de Flodoard (Paris, 1906), s.a. 959, p. 146.

${ }^{44}$ West, Reframing the Feudal Revolution, pp. 109-138.

${ }^{45}$ Folcuin, Gesta, c. 26, pp. 67-69.

${ }^{46}$ Folcuin, Gesta, c. 22, p. 64.

${ }^{47}$ Theodor Sickel (ed.), Die Urkunden Konrad I., Heinrich I. und Otto I., MGH Diplomata regum et imperatorum Germaniae 1 (Hanover, 1879-1884), no. 322; Gerhard, Vita S. Oudalrici Episcopi, ed. Georg Waitz, MGH SS 4, c. 28, pp. 415-416; Karl Leyser, "Ottonian Government," English Historical Review 96 (1981), 721-753, at 750-751.

${ }^{48}$ Ruotger of Cologne, Vita Brunonis, ed. Irene Schmale-Ott, MGH SRG NS (Weimar, 1951), c. 39, pp. 41-42. Writing around the same time, Widukind of Corvey, Rerum Gestarum Saxonicarum, 1.30, 2.15, 2.36, pp. 42-43, 79-80, 95-97 was considerably less scathing.

${ }^{49}$ Thietmar, Chronicon, 6.48, p. 334; trans. David Warner, Ottonian Germany (Manchester, 2001), pp. 270-271.

${ }^{50}$ Robert Bartlett, Gerald of Wales: 1146-1223 (Oxford, 1982), pp. 158-177.

${ }^{51}$ Robert Bartlett, "Heartland and Border: the Mental and Physical Geography of Medieval Europe," in Huw Pryce and John Watts (eds.), Power and Identity in the Middle Ages. Essays in Memory of Rees Davies (Oxford, 2007), pp. 23-36.

${ }^{52}$ Quote: Paul Connerton, How Modernity Forgets (Cambridge, 2009), p. 5.
} 
compounded the effects of dynastic instability in disrupting the writing of history and complicating the relevance of the past to the present.

This shift also helps us realise that Aachen did not occupy the same position in the Ottonian system of places as it had in the time of the Carolingian Empire, and this in turn might make us think twice about the meaning of the nascent coronation tradition associated with the site. Given the contested politics of the region, it can be argued that most of these coronations were not simple performances of dynastic majesty, but also had secondary audiences. Otto I's inauguration in August 936 took place a matter of weeks after the coronation at Laon of Louis IV, the teenaged son of Charles the Simple whose unarguable Carolingian credentials gave weight to his ambitions to re-take Lotharingia; Otto's decision to stage his own crowning in Aachen can be interpreted as an anxious attempt to pre-empt this possibility and push Ottonian claims to the middle kingdom (which hitherto had been fragile at best). ${ }^{53}$ Widukind's much-discussed description of the coronation lays heavy stress on the Frankish and Carolingian connotations of the occasion, but it is interesting that he appeals to these traditions really only at this point in his text, and amidst a pile of other historical references. ${ }^{54}$ Moreover if, as is generally argued, Widukind was writing in 966-7, his description was composed in the wake of a rare direct intervention in the Aachen area by Otto I, who in early 966 visited Cologne and "arranged all the affairs of the Lotharingian kingdom as he deemed suitable". ${ }^{55}$ It was on this occasion that Otto issued a remarkably verbose charter which refers to the legacy of Charlemagne and describes the palace complex at Aachen (the charter's recipient), as "the most important royal seat this side of the Alps". ${ }^{56}$ In other words, both the choice of Aachen for the coronation and the nature of Widukind's account must be interpreted in the context of Ottonian self-assertion in northern Lotharingia in 936 and 966-7.

The other key examples can also be seen in light of the region's contested politics. Otto II's coronation at Aachen in 961 was in fact his second, and was specifically intended to elicit "the agreement and election of all the Lotharingians". ${ }^{57}$ The implication is that the latter group needed to be consulted separately from the bulk of the East Frankish aristocracy, and on their own territory, having failed to attend his prior coronation in Worms - hardly a sign that this was an unproblematic staging of royal majesty. Otto III's coronation at Aachen in 983 was likewise a supplementary event which followed an initial inauguration at Verona. ${ }^{58}$ Aachen also played a role in the manoeuvrings surrounding the disputed succession to the childless Otto III in 1002. This took the form of a struggle to control his funeral, which eventually took place at Charlemagne's famous palace. But while it would be easy to assume that this outcome simply reflected Otto's own well-attested interest in his great predecessor,

${ }^{53}$ Timothy Reuter, Germany in the Early Middle Ages, 800-1056 (London, 1991), p. 148. For Henry I's limited influence in Lotharingia, where he ruled through intermediaries, see Adalbert, Continuatio, s.a. 931, pp. 158-159.

${ }^{54}$ Steve Robbie, "Can Silence Speak Volumes? Widukind's Res Gestae Saxonicae and the Coronation of Otto I Reconsidered," Early Medieval Europe 20 (2012), 333-362.

${ }_{55}$ Adalbert, Continuatio, s.a. 966, p. 177.

${ }^{56}$ Adalbert, Continuatio, s.a. 961, p. 171; Die Urkunden Ottos I., no. 316: "hoc palatium precipua cis Alpes regia sedes". Cf. Thomas Zotz, "Symbole der Königsmacht und Spiegel gesellschaftlicher Interaktion: zur Rede von palatium in den Urkunden der Ottonen," in Sylvain Gouguenheim et al (eds.), Retour aux sources. Textes, études et documents d"histoire offerts à Michel Parisse (Paris, 2004), pp. 363-372, at pp. 363-366.

${ }^{57}$ Adalbert, Continuatio, s.a. 961, p. 171; Ruotger, Vita Brunonis, c. 41, pp. 43-44.

${ }^{58}$ Gerd Althoff, Otto III (University Park, 2003), pp. 29-30. 
conflicts among the living were at least as important. The impresario of the elaborate funeral was Archbishop Heribert of Cologne, who supported the succession claims of Herman of Swabia and in whose backyard Aachen lay. Not coincidentally, the texts that claim Otto III wished to be interred there are also markedly pro-Heribert. Meanwhile, the party supporting Herman's main rival Henry of Bavaria, which had failed to gain control of the dead king's body, was led by Archbishop Willigis of Mainz. The succession dispute was therefore linked to a conflict over which churchman had the right to oversee the burial of the old king and the inauguration of the new; the choice of Aachen was clearly conditioned by these circumstances. ${ }^{59}$ Despite Heribert's initial success, in the end Henry was the victor and accordingly his coronation was staged at Mainz. It was only when he decisively gained the upper hand in later in 1002 that he visited Aachen for a second coronation, in which the archbishop of Cologne (whom Henry had recently imprisoned) refused to participate. As in 961, this was an election specifically conducted for an audience of "the Lotharingians" who had not yet submitted to the new king's authority.

Our main source for all this is the pro-Henry Thietmar, whose claim that the new king's enthronement at Aachen was conducted "according to the custom of his ancestors" is clearly somewhat disingenuous - and indeed forms part of the dispute it purports to describe. In retrospect the event did sit in an emerging tradition of Ottonian inaugurations, but at the time it took place in response to a very specific set of circumstances: it was primarily intended to impress or win over a local political faction which had previously resisted the new ruler. ${ }^{60}$ This often-overlooked interplay between Aachen's regional significance and its broader historical resonance did not end there: although his biographer Wipo depicts Conrad II's post-coronation visits to Aachen in 1024-5 in terms of the new king's desire to lay claim to "Charlemagne's throne", in fact his visit was at least partly influenced by a need to pre-empt the expansionary ambitions of Count Odo of Champagne, who had threatened to occupy the palace over Christmas, and to win over the Lotharingians who had been hostile to his election. Conrad's only other visit, over a decade later, had a similar context. ${ }^{61}$ The contours of such disputes were not simply dictated by inherited political traditions. In fact, the reverse might be true: these traditions were themselves conjured into being (by the likes of Thietmar) in large part as a response to the disputes.

\footnotetext{
${ }^{59}$ Joachim Ehlers, "Magdeburg-Rom-Aachen-Bamberg. Grablege des Königs und Herrschaftsverständnis in ottonischer Zeit," in Bernd Schneidmüller and Stefan Weinfurter (eds.), Otto III.-Heinrich II.: Eine Wende? (Sigmaringen, 1997), pp. 47-76, at pp. 58-64; Weinfurter, "Authority and Legitimation," pp. 29-30. For a longer context in the Mainz vs Cologne rivalry see Erkens, "Ex iure".

${ }^{60}$ Thietmar, Chronicon, 5.20, p. 245. Likewise, Henry's visit to Aachen in 1003 was to enable him to "meet with the Lotharingians as a whole" (Thietmar, Chronicon, 5.28, p. 253). On the various post-fact justifications given for Henry's succession see Patzold, "Königserhebungen zwischen Erbrecht und Wahlrecht?"

${ }^{61}$ Wipo, Gesta Chuonradi II imperatoris, ed. H. Bresslau, MGH SRG (Hanover and Leipzig, 1915), cc. 2, 6, pp. 19-20, 27-29. Cf. Herwig Wolfram, Conrad II, 990-1039. Emperor of Three Kingdoms (University Park, 2006), pp. 56-58, 72-76, 183-184; Björn Weiler, "Describing Rituals of Succession and the Legitimation of Kingship in the West, ca. 1000 ca. 1150," in Alexander Beihammer et al (eds.), Court Ceremonies and Rituals of Power in Byzantium and the Medieval Mediterranean (Leiden and Boston, 2013), pp. 115-140, at pp. 118-124. On Odo see West, Reframing the Feudal Revolution, pp. 126-129.
} 
These kings and their supporters may have been thinking global, but they were acting local. The fact that northern Lotharingia was contested territory raises the possibility that performing their royal status at Aachen was not simply a means by which rulers laid claim to the legacy of Charlemagne. What if, on the contrary, they needed to appropriate the memory of Charlemagne as a means of laying claim to Aachen and its hinterland? Of course, these possibilities are not mutually exclusive. But it is possible to argue that even for the two rulers whose interest in the ninth-century Carolingians is clearest, the middle kingdom was a crucial setting: Charles the Simple's royal documents proclaimed his annexation of Lotharingia in 911 as the moment at which he came into his full Carolingian inheritance; and Otto III's interest in Charlemagne manifested itself specifically at Aachen. ${ }^{62}$ As important as it was to them, even for Charles and Otto Lotharingia remained a region at the edge of their reach, and Aachen a former political centre rendered peripheral by tenth-century reconfigurations of Carolingian political geography. In this light, post-Carolingian Aachen might be thought of as a "site of memory" in the sense described by Geoffrey Cubitt as "quintessentially residual...bring[ing] into focus not the existence of still living communities of memory, but merely the lingering awareness of memories and traditions that once had social meaning." $" 63$ The palace was still rich with meaning, but the world around it had changed irrevocably. Read against the grain, the loudly-proclaimed Carolingian credentials of Aachen might in fact be read as another symbol of the discontinuousness of Carolingian political consciousness and traditions in the tenth century. ${ }^{64}$

A third and final way of sampling post-Carolingian attitudes to the past can be found in charters. Historians now see royal diplomas as much more than the dry administrative documents of nineteenth-century legal history. Via their formulas, narratives and seals, they acted as a medium of communication between rulers and recipients, as quintessential symbols of Frankish cultural belonging and, consequently, as "trace elements" which can be used to map the expansion of Europe. ${ }^{65}$ Moreover, the micro-narratives and references to grants made by earlier rulers contained in royal charters also articulated and transmitted a form of episodic memory. This is not just a modern observation but something that that was fully recognised

${ }^{62}$ Charles: Jens Schneider, Auf der Suche nach dem verlorenen Reich. Lotharingien im 9. und 10. Jahrhundert (Cologne, Weimar and Vienna, 2010), p. 120. Otto: Ludwig Falkenstein, Otto III. und Aachen (Hanover, 1998).

${ }^{63}$ Geoffrey Cubitt, History and Memory (Manchester, 2007), p. 47 (here discussing the ideas of Pierre Nora).

${ }^{64}$ Aachen was "quoted" architecturally in other places of power, but this is a primarily post1000 phenomenon: Thomas Zotz, "Carolingian Tradition and Ottonian-Salian Innovation: Comparative Perspectives on Palatine Policy in the Empire," in Anne Duggan (ed.), Kings and Kingship in Medieval Europe (London, 1993), pp. 69-100; Jenny Shaffer, "Letaldus of Micy, Germigny-des-Prés, and Aachen: Histories, Contexts, and the Problem of Likeness in Medieval Architecture," Viator 37 (2006), 53-84.

${ }^{65}$ Bartlett, Making of Europe, p. 286. On charters see now Hagen Keller, "Zu den Sieglen der Karolinger und der Ottonen. Urkunden als 'Hoheitszeichen' in der Kommunikation des Königs mit seinem Getreuen," Frühmittelalterliche Studien 32 (1998), 400-441; Hagen Keller, "Ottonische Herrschersiegel. Beobachtungen und Fragen zu Gestalt und Aussage und zur Funktion im historischen Kontext," in H. Keller, Ottonische Königsherrschaft. Organisation und Legitimation königlicher Macht (Darmstadt, 2002), pp. 131-166; Koziol, Politics of Memory. 
in the tenth and eleventh centuries, when charters were used to construct the histories of nunneries, monasteries and bishoprics where none had existed before. ${ }^{66}$

Wherever we look in this material, we meet the Carolingian past: the scribes who wrote the texts (whether they worked for the granter or the recipient) habitually referred to past rulers whose earlier gifts were being confirmed or enhanced, and often positioned post-Carolingian kings in a royal continuum beginning in the seventh, eighth or ninth centuries. But in view of the fact that diplomas were designed to communicate the stylised ideologies of kingship (which in general terms show few major breaks with existing models), it is perhaps surprising that very few of the hundreds of tenth-century examples drew specific attention to Carolingian precedent. Indeed, in some ways it was tacitly rejected: the Ottonians consistently and studiously avoided appropriating the titulature of their predecessors. ${ }^{67}$ Royal seals also show a clear break with the past. By the 920 s rulers in all parts of the former empire had relinquished Carolingian iconographies, and from the middle of the tenth century a new Ottonian imperial seal became a standard model imitated even by the West Frankish descendants of Charles the Simple. ${ }^{68}$ And even though it was customary for the drafters of royal charters to invoke past kings as predecessors of the current ruler, sometimes in a very pointed way, they by and large chose not to instrumentalise Carolingian kings as models even Charlemagne, who is generally assumed to have been a touchstone for legitimate kingship from his death in 814. West Frankish charters refer to Charlemagne surprisingly rarely, and he does not stand out in eastern diplomas either. Although a proper statistical analysis would need to take into account the complexities of authorship, survival and genre, and therefore might well be impossible, we can gain at least a crude sense of the historical horizons of the post-Carolingian world by counting references to past rulers. Of 163 references to Carolingian predecessors in the charters of the first three non-Carolingian kings in the east (911-73), 42 (26\%) are to Charlemagne, and in the few examples where he is identified as a specific model, it is not as a paragon of kingship per se but as a founder of churches. This is typical of the way he was remembered by the ruling classes of Saxony, who thus positioned themselves at the forefront of European expansion and authorised their own religious-colonial ambitions in the east. ${ }^{69}$

By the twelfth century, as is well known, Charlemagne had indeed become ubiquitous, a towering figure whose reputation all but obscured the other kings of his dynasty; in the charters of Frederick Barbarossa (1152-90) over half the references to Carolingian kings were to the great Charles. This reflects the mythologizing of Charlemagne as he was abstracted from his historical context and recast as an iconic and omnipresent figure, appropriated as a

${ }^{66}$ Geary, Phantoms of Remembrance, pp. 81-114; Riches, "Changing Political Horizons". ${ }^{67}$ Eckhard Müller-Mertens, "Frankenreich oder Nicht-Frankenreich? Überlegungen zum Reich der Ottonen anhand des Herrschertitels und der politischen Struktur des Reiches," in Carlrichard Brühl and Bernd Schneidmüller (eds.), Beiträge zur mittelalterlichen Reichs- und Nationsbildung in Deutschland und Frankreich (Munich, 1997), pp. 45-52.

${ }^{68}$ Keller, "Ottonische Herrschersiegel."

${ }^{69}$ Keller, "Die Ottonen." For parallel lack of attention among tenth-century bishops to Carolingian synodal authority per se, see Ernst-Dieter Hehl, "Die Synoden des ostfränkischdeutschen und des westfränkischen Reichs im 10. Jahrhundert. Karolingische Traditionen und Neuansätze," in Wilfried Hartmann and Annette Grabowsky (eds.), Recht und Gericht in Kirche und Welt um 900 (Munich, 2007), pp. 125-150. 
potent predecessor even (or especially) in regions he had hardly visited. ${ }^{70}$ But in the Frankish heartlands in the twelfth century, it was still at Aachen itself where Charlemagne's reputation was most carefully nurtured and insistently advertised. ${ }^{71}$ The Charlemagne of the twelfth century was a specifically imperial figure, with his Roman coronation of 800 a key part of the origin story of the medieval German empire as it emerged in the "universal" histories of the period. ${ }^{72}$ But the real origins of this Charlemagne were comparatively recent, and lay in the nascent imperial-papal conflicts of the mid-eleventh century. It is surely not a coincidence that the first ruler whose charters make a pronounced reference to Charlemagne as the starting point for a sequence of rulers running up to the present was Henry IV, who in a series of diplomas from 1063 declared that he saw himself acting in imitation of "our predecessors the emperors of the Romans and kings of the Franks from the great Charles up to our own times". ${ }^{73}$ Such a statement is not surprising in the context of what we know about Charlemagne's posthumous reputation - but what is surprising is that we do not find this sentiment expressed so clearly by earlier rulers, other than in the setting of Aachen. The elements of tenth-century political discourse sampled in this article do not show this level of attachment to Carolingian precedent, and seem to indicate a sense of the Carolingian past as distant - as past. Whatever the trajectories of its social and economic development, the world from whose "fertile confusion" Europe was made was thus post-Carolingian not just in the jargon of modern historians, but also at the level of contemporary historical consciousness. Charles the Simple protested too much: he not only lived in a post-Carolingian world, he surely also knew it. It was left to his successors, like Otto III, Henry IV and Frederick Barbarossa, to forget. ${ }^{74}$

\footnotetext{
${ }^{70}$ Amy Remensnyder, Remembering Kings Past: Monastic Foundation Legends in Medieval Southern France (Ithaca, 1995).

${ }^{71}$ Knut Görich, “Karl der Große - ein 'politischer' Heiliger im 12. Jahrhundert?” in Ludger Körntgen and Dominik Waßenhoven (eds.), Religion und Politik im Mittelalter. Deutschland und England im Vergleich (Berlin and Boston, 2013), pp. 117-155.

${ }^{72}$ Richard Southern, History and Historians, ed. Robert Bartlett (Oxford, 2004), pp. 11-86; Timothy Reuter, "Past, Present and No Future in the 12th-Century Regnum Teutonicum," in Paul Magdalino (ed.), The Perception of the Past in Twelfth-Century Europe (London, 1992), pp. 15-36; Johanna Dale, "Imperial Self-Representation and the Manipulation of History in Twelfth-Century Germany: Cambridge, Corpus Christi College MS 373," German History 29 (2011), 557-583. .

${ }^{73}$ Dietrich von Gladiss and Alfred Gawlik (eds.), Die Urkunden Heinrichs IV., MGH
} Diplomata regum et imperatorum Germaniae 6 (Hanover, 1941-1978), nos. 103, 108, 112, 113, 115: "a Karolo magno predecessores nostri Romanorum siquidem imperatores vel Francorum reges usque ad tempora nostra." These were mostly written for and in collaboration with the church of Hamburg-Bremen, whose archbishop Adalbert was Henry's main protector and adviser - they can thus be seen as reflecting the "official" discourse of the court at this moment. For Charlemagne as precedent see also nos. 254, 283. NB also most of the numerous forged diplomas attributed to Charlemagne date from the eleventh and twelfth centuries: Constance Brittain Bouchard, Remembering Saints and Ancestors. Memory and Forgetting in France, 500-1200 (Philadelphia, 2015), pp. 63-4 On attitudes to Charlemagne in the eleventh- and twelfth-century Empire, Latowsky, Emperor of the World, is now the starting point.

${ }^{74}$ For comments and criticism I am grateful to Stuart Airlie, Max Diesenberger, Jinty Nelson, Theo Riches and Charles West. 